\title{
Cluster Competitiveness Analysis: A Brazilian Case
}

\author{
Elizangela Maria Menegassi de Lima ${ }^{1,2}$ [0000-0003-4440-224X] , Isabela Romanha de Alcan- \\ $\operatorname{tara}^{2[0000-0001-9172-4271}$, Jose Benedito Sacomano ${ }^{2[0000-0002-4877-3139]}$ and Ana Paula de \\ Lima da Silva ${ }^{2[0000-0002-9239-4363]}$ \\ ${ }^{1}$ Paranaense University- UNIPAR, Academic, Umuarama, P.R., Brazil \\ ${ }^{2}$ Paulista University-UNIP, Postgraduate Program in Production Engineering \\ Rua Dr. Bacelar, 1212, Sao Paulo, SP, Brazil, 04026-000 \\ menegassieprof.unipar.br
}

\begin{abstract}
The objective of this study was to compare the factors related to the development stage and the level of competitiveness of the furniture cluster located in the northwestern region of Paraná / Brazil. For the development of the research, descriptive approaches with quantitative and qualitative procedures were used. As a data collection instrument, a cross-sectional survey was applied with 20 companies in the sector. The data were interpreted from a statistical analysis using the average of the relative frequencies. The results indicated that the competitiveness index is unfavorable and the cluster is in initial stage, pointing out fragility, mainly in the item government policies.
\end{abstract}

Keywords: Cluster, Competitiveness Factors, Cluster Ranking

\section{Introduction}

Organizations need competitiveness to manage their businesses, in face of the turbulence imposed by the globalized economic environment [1]. In addition, companies are seeking to adjust to the new competitiveness standards, to the impact of technologies on competitiveness, to cultural influences and to different interfering factors in the organizations routines [2, 3].

The management of local productive arrangements (LPA), through collective actions between the companies, whether they are suppliers of goods or services, is an impressible strategy to obtain competitive advantages in the local markets, contributing considerably to the increase of companies' profitability and growth $[1,4,5]$. However, the analysis of competitiveness in productive agglomerations is based on human capital, governance, logistics infrastructure, collective efficiency, productive cooperation, technological innovation, quality, productivity, government policies and training programs.

The aim of this study is comparing factors related to the development stages and the level of competitiveness in the Northwestern Paraná furniture cluster. For this, a survey was applied to the companies belonging to the sector under study, considering the internal and external factors involved in the competitiveness context, for the analysis of the level of maturity of the cluster. It is inferred that the analysis of the pro- 
posed factors allows determining the capacity of the companies in the sector, aiming at the development of competitive advantages and strategies that are feasible for the growth and development of the local and regional economy.

\section{Literature Review}

\subsection{Competitive Clusters}

The formation of regional clusters and local productive systems are strategies of geographic concentrations of companies and institutions interconnected in a particular field, involving suppliers, machines, services and infrastructure, to provide conditions of competitiveness [1, 4].

Clusters promote competition and co-operation among firms to engage and retain customers $[1,6]$. Cooperation is carried out vertically, involving related companies and local institutions. Basically, the arrangements affect the competitiveness in three levels: increase of the productivity of the companies, direction and pace of the innovations and stimulation of the formation of new businesses [1, 7].

Clusters can be classified according to the stage of development, offering subsidies for the development of related public policies [7, 8].

The stages specified in Figure 1 below show that in the initial stage called precluster, firms and industries are independent existing a regional concentration of the same productive chain; and at the emergent stage, the cluster is at the beginning of the development process, anticipating a possible overrun of the embryonic stage, with the government acting for the regional industry with the consequent action of incentive policies. The expanding cluster increases the links between companies by promoting the growth of collective actions between them. At this stage, local actors actively participate in support mechanisms to attract potential domestic and international competitors to the cluster. In the last stage, understood as a mature cluster, there is a phase of maturity in the institutional, commercial, industrial, environmental and local sphere with solid mechanisms of information sharing, inter-company cooperation and diffusion of innovation and knowledge [7, 8].

\section{Steps in forming a cluster}

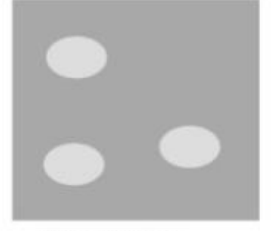

Pre clusters Companies and independent
industries

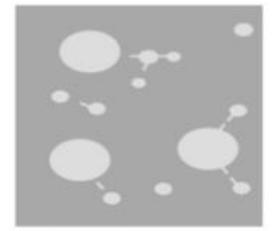

Emerging cluster intercompans intercompany
and industry

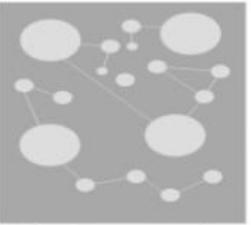

Cluster expansion Increase
links

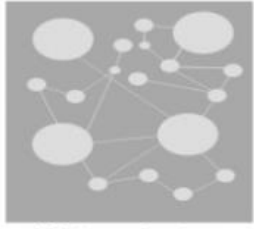

Mature cluster High level links intercompany
critical mass

Fig. 1. Cluster classification.

The arrangements favor cooperation, solidarity and reciprocity, with the presence of local institutions to understand and sustain the systems. Some conditions are rele- 
vant to the development of arrangements such as the significant number of firms and agents, specialization in a specific productive activity, as well as the existence of skilled local labor and correlated activities $[7,9,10]$.

\subsection{Competitiveness Factors among Cluster Operating Systems}

Following, is presented factors of analysis related to the competitiveness of an agglomeration, which serves as a reference for a possible assessment of this study.

Human Capital. Organizations with dynamic environments are constantly changing to develop and empower people, aiming to obtain better results in the activities developed, with investments in education, incorporation of centers and even universities to offer training and development of people [10, 11].

Governance. This concept is linked to the idea of development management that consists of a set of mechanisms of administration of a social system and organized actions, with the intention of guaranteeing security, prosperity, coherence, order and continuity of the system itself [12]. Therefore, governance advocates viable forms of administration to meet the aspirations of most of the people (actors) involved, leading to healthy management of business development $[7,12]$. This concept is linked to the idea of development management.

Logistic Infrastructure. This expression aims to analyze the set of facilities (factories and storage points) and means of transportation used by the supply chain of the productive arrangement to achieve objectives. The logistic factor is a key element in supply chain considerations and in the movement of products and materials to organizations [13]. This way, the more strategic the cluster is in relation to its location, the better its competitiveness in the market will be.

Collective Efficiency The collective actions in networks, associations, agglomerations imply opportunities and risks. They exist in a group of different agents, connected to each other, for distinct reasons, which may be financial, technological, cultural, among others [14]. In a competitive scenario which is complex and unpredictable, small and medium-size businesses may find difficulty to achieve their goals. Collective initiatives contribute to overcome such difficulties [15].

Intercompany Cooperation. This system of cooperation is based on a set of independent small businesses, organized in a local and / or regional basis. These individual companies use local institutions, integrating relationships, competition and cooperation $[16,17]$. Sharing a value activity, results in a significant cost advantage, presenting an important fraction of assets or operating costs. 
Technologic Innovation. The management of technology uses administration techniques in order to maximize the technological potential as a support tool for the organization, contributing to cost reduction, improvement in the development of products and reducing lead times for innovations [7, 18]. When it comes to clusters, this element is necessary for a competitive activity, considering that over time the technological of companies tends to become outdated, anachronistic and obsolete [7].

Quality. Quality in the production process is determined and perceived by the customer, being decisive at the moment of purchase. Quality control is essential to ensure product reliability, compliance, durability and aesthetics $[12,13]$.

Productivity. Productivity is crucial in the company competitiveness to measure the efficiency of an operational system, in relation to its products and goods used in the production. Productivity efficiency is developed when there is collaboration among employees, making the values of the company be verified in all its hierarchy levels, making productivity a collective goal [13].

Government Institutions (Support Policies). Interaction and cooperation among companies is overriding for the development, promoting collective actions and information sharing, knowledge and infrastructure. External support institutions belonging to the cluster involve public institutions (local, regional and federal), entities, fomentation agencies, support institutions and associations representing the company in the several branches of the chain $[19,20]$.

Training Programs. Such programs contribute to show the strategic profile of the company to all its staff, integrating and stimulating differences and promoting quality in the operations. The maintenance and development of staff are the pillars of sustainability of any organization. Considering that the companies need to have as goals a good strategic plan and investments in programs which aim at a great operational climate and the guarantee of financial return [21].

\section{$3 \quad$ Methodology}

This study was applied in the furniture sector of the region of Umuarama, located in the south of Brazil. The approach was descriptive, with quantitative and qualitative procedures, using the survey, aiming to contribute to the knowledge of a particular area of interest, through the collection of data/information about individuals or the environment.

In the data collection phase, 20 structured questionnaires were applied to the managers of the companies belonging to the agglomeration studied, in the second semester of 2016, containing closed questions using Likert scale of five points, to analyze the competitiveness factors and the development stage of the furniture cluster. 
The relative frequency average was used as statistical tool. Let $f(i)$ be the relative frequency over the competitiveness level of the cluster under study, covering a range $[0,100 \%]$ over real numbers. Let $\mathrm{X}_{\mathrm{Fr}}$ be measured on a semantic scale, then the average of the relative frequencies $\left(\mathrm{X}_{\mathrm{Fr}}\right)$ can be calculated with the aid of Eq. 1 below:

$$
X_{F r}=\frac{1}{n \cdot k} \cdot \sum_{i=n}^{n} i \cdot \sum_{j=1}^{k} f_{j}(i)
$$

Where $i=-2,-1,0,1,2, \ldots, \mathrm{n} ; \mathrm{n} \in \mathrm{Z}$, is the weight attributed to the level of competitiveness on the semantic scale, where zero is the equilibrium (origin) and $f(i)$ is the relative frequency on the level $i$ and $k$ is the number of variables with $j=1,2, \ldots, k$, under these conditions, $\mathrm{X}_{\mathrm{Fr}} \in[-100 \%, 100 \%]$ in the real numbers.

To better understand the results obtained in the statistical analysis, a scale divided into eight intervals was constructed to measure competitiveness, as shown in Figure 2.

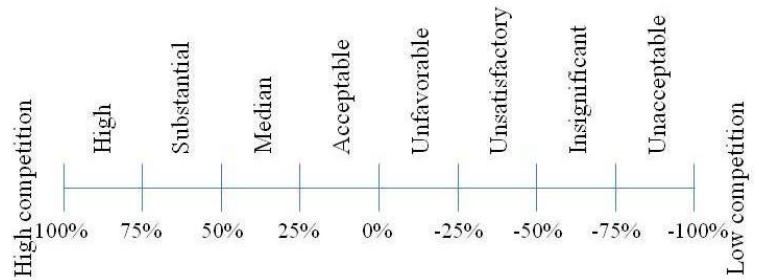

Fig. 2. Low and High Competitiveness Scale.

\section{$4 \quad$ Results and Discussion}

In the area of furniture, the Paraná currently has three local productive arrangements, in the north, northwest and southwest. This survey focused on the furniture sector of the northwest region, on competitive factors. Out of the companies interviewed, $47 \%$ are in the upholstery furniture sector; $39 \%$ represent the mattresses business; and $14 \%$ are part of the tailored furniture.

This sector is representative in the local economy. The wood and furniture industries represent $19 \%$ of the region's commercial establishments, directly creating one thousand three hundred and forty-nine jobs. The levels of satisfaction, in relation to competitiveness factors, have been measured and tabulated, in percentage, according to Table 1 below.

Table 1. Analyzis of Competitiveness Factors (in percentage).

\begin{tabular}{|c|c|c|c|c|c|c|}
\hline \multirow{2}{*}{ Question } & Competitiveness Assessment & Awful & Bad & Regular & Good & Excellent \\
\hline & Competitiveness Analysis & $(-2)$ & $(-1)$ & (0) & $(+1)$ & $(+2)$ \\
\hline $\mathrm{Q}_{1}$ & Human Capital & 5.0 & 20.0 & 45.0 & 15.0 & 15.0 \\
\hline $\mathrm{Q}_{2}$ & Governance & 35.0 & 15.0 & 30.0 & 15.0 & 5.0 \\
\hline $\mathrm{Q}_{3}$ & Logistic Infrastructure & 5.0 & 10.0 & 10.0 & 45.0 & 30.0 \\
\hline $\mathrm{Q}_{4}$ & Collective Efficiency & 55.0 & 15.0 & 10.0 & 20.0 & 0.0 \\
\hline$Q_{5}$ & Production Cooperation & 60.0 & 10.0 & 10.0 & 15.0 & 5.0 \\
\hline $\mathrm{Q}_{6}$ & Technological Innovation & 10.0 & 15.0 & 50.0 & 20.0 & 5.0 \\
\hline $\mathrm{Q}_{7}$ & Quality & 0.0 & 0.0 & 40.0 & 20.0 & 40.0 \\
\hline Q8 & Productivity & 0.0 & 5.0 & 45.0 & 25.0 & 25.0 \\
\hline$Q_{9}$ & Adequate Government Policies & 70.0 & 0.0 & 20.0 & 10.0 & 0.0 \\
\hline$Q_{10}$ & Training Programs & 50.0 & 30.0 & 10.0 & 5.0 & 5.0 \\
\hline \multicolumn{2}{|l|}{ TOTAL } & 290 & 120 & 270 & 190 & 130 \\
\hline
\end{tabular}


Assigning weight in a weighted way (appalling -2 , bad -1 , average 0 , good +1 , excellent +2 ) according to the results obtained, on the internal side Figure 3 shows the low competitiveness; and on the external side aspects of high competitiveness.

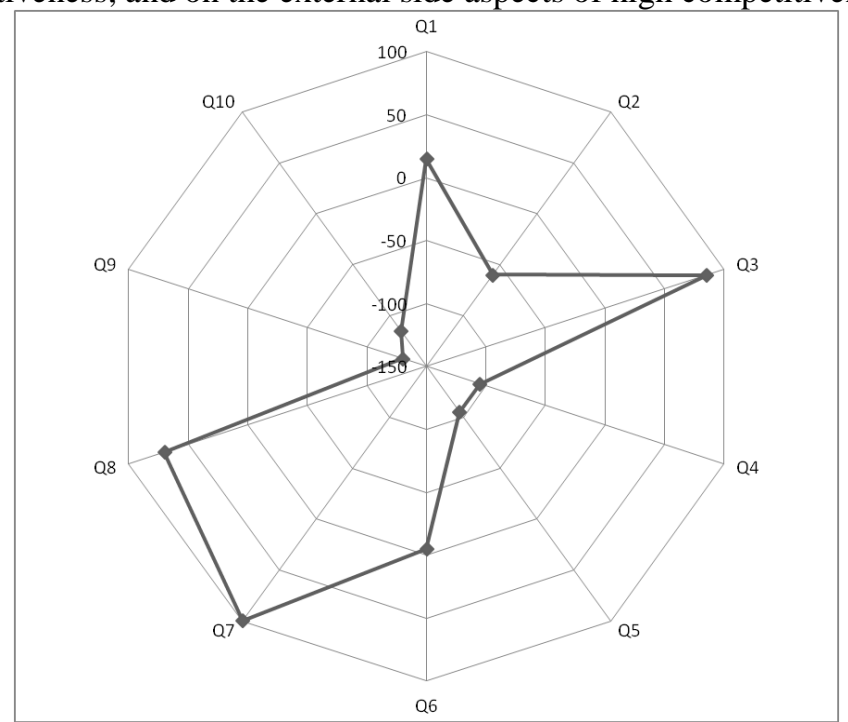

Fig. 1. Graphic Representation of Relative Frequency.

According to the image above, the results show positive and negative answers, in relation to the competitiveness elements. Among the positive items are logistic infrastructure (Q3) and quality (Q7). Among the negative items are government policies (Q9) and training programs (Q10).

The logistic infrastructure has as a sum of good and excellent results in $75 \%$ of the answers, indicating that it is a highly competitive element. This item is related to the physical distribution of products, both internal and external, storage, and layout of work tools within the company.

The quality aspect was the excellence of $40 \%$ of its responses, and represents one of the elements invested by entrepreneurs in the region as a competitive advantage; another $40 \%$ assessed quality as average, evidencing the discrepancy between the priorities of the companies.

In government policies, $70 \%$ of the answers were assessed as appalling, representing the worst result in the survey. External influence is a factor which makes competitiveness hard.

As for training programs developed in the cluster, 50\% of the interviewed assessed this item as appalling. It was found that cluster managers do not invest in the development and training of their staff, which may lead to demotivation.

In general, the relative frequency average was carried on according to Eq. 2, and the results obtained are shown in Figure 4.

$$
M f_{r_{=}(-2) \cdot(290.0)+(-1) \cdot(120.0)+(0) \cdot(270.0)+(+1) \cdot(190.0)+(+2) \cdot(130.0)}^{2 \cdot 10}=-12.5 \%
$$




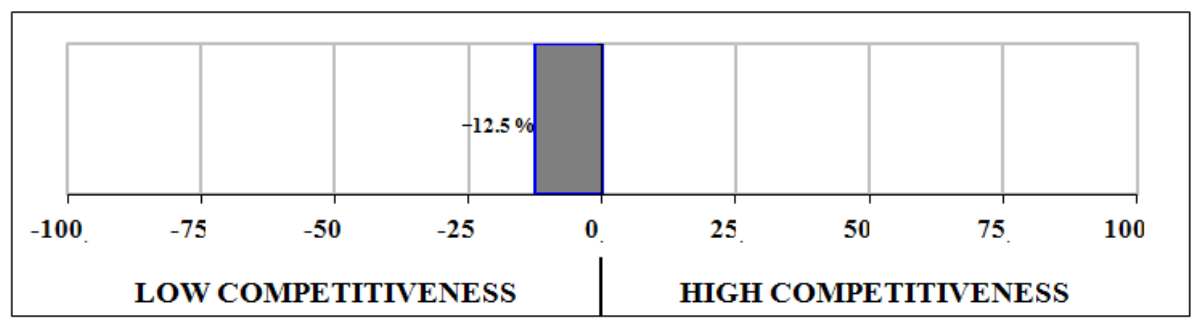

Fig. 4. Average Relative Frequency Result.

An assessment conducted with the cluster managers on competitiveness, related to the above-mentioned items, resulted in $-12.5 \%$, obtained by the relative frequency average. It was concluded that it is an unfavorable result, according to the scale used to assess the Relative Frequencies Average. In such analysis, it can be inferred that the answers of managers tend to be more negative, rather than positive.

\section{Conclusion}

The competitive analysis in the furniture sector, in relation to companies from the cluster, contributes to the obtaining of a view closer to reality about the strengths and weaknesses of the local productive arrangement, aiming at the possibility of collective actions directed to furniture companies.

This study showed that the stage of development of the furniture cluster in Umuarama, Paraná/Brazil is still embryonic. The analysis of competitive elements showed an unfavorable percentage.

Such analysis requires actions for the development and growth of the local economy. In this way, the importance of the study of corporate networks is noticeable, since new forms of governance in productive arrangements are frequent nowadays, as a way of expanding and generating competitive advantages for the companies participating in the local arrangements.

\section{References}

1. Porter, M.: Location, Competition, and Economic Development: Local Clusters in a Global Economy. Economic Development Quarterly. 14, pp.15 (2000).

2. Tilahun, N., Fan Y.: Transit and Job Accessibility: an Empirical Study of Access to Competitive Clusters and Regional Growth Strategies for Enhancing Transit Accessibility. Transp. Policy. 33, pp.17-25 (2014).

3. Huggins, R., Thompson, P., Johnston, A.: Network capital, social capital and knowledge flow: how the nature of inter-organizational networks impacts on innovation. Industry and Innovation, 19, pp. 203-232. (2012).

4. Marshall, A. Principles of Economics. 8th ed. London: Macmillan and Co, Ltd. (1920). 
5. Söylemezoglu, E., Doruk O. T.: Are Clusters Efficiente for the Relation Betweem Milk Production and Value Added per Capita in Regional Level? An Empirical Assessment. Proc. Social Behav. Sciences 150, pp.1277-1286 (2014).

6. Huggins R., Izushi H.: Competition, Competitive Advantage and Clusters: The Ideas of Michael Porter. Oxford University Press (2011).

7. Amato Neto J.: Gestão de Sistemas Locais de Produção e Inovação (clusters/APLS): um Modelo de Referência. São Paulo: Atlas (2009).

8. Oliveira, J. A. P. Pequenas empresas, arranjos produtivos locais (APLs) e sustentabilidade, Rio de Janeiro: FGV, (2009).

9. Negrusa, A. L.; Rus, R. V.; Soficã, A. Innovative tools used business networks and clusters in communication. Procedia - Social and Behavioral Sciences. 148 (2014).

10. Vandarlier, P. Strategic approach to human resources management during crisis. ProcediaSocial and Behavioral Sciences 235, pp. 462-472 (2016).

11. Becher, K.; Smidt, M. A risk perspective on human resource management: a review and directions for future research. Human Resource management Review 26, pp. 149-165 (2016).

12. Costa Neto, P. L. O.; Canuto, S. A .: Administraçao com qualidade: conhecimentos necessarios para a gestao moderna. São Paulo: Blucher, (2010).

13. Reis, J. G. M.; Neto, M. M.; Vendrametto, O.; Costa Neto, P. L. O.: Qualidade em redes de suprimentos: a qualidade aplicada ao suplly chain management. Sao Paulo: Atlas (2015)

14. Olson, M. A Lógica da Ação Coletiva: os Benefícios Públicos e uma Teoria dos Grupos Sociais. São Paulo: Editora da Universidade de São Paulo (2011).

15. 17. Ostrom, E. Collective Action and Local Development Process. Sociologia. Bologna, (2007).

16. Williams, T. Cooperation by design: structure and cooperation in interorganizational networks. Journal of Business Research, volume 58, pp. 223-231 (2005).

17. Wäsche, H. Interorganizational cooperation in sport turism: A social network analysis. Sport management Review. (2015).

18. Fundeanu, D. D.; Badele, C. S. The Impact of Regional Innovative Cluters on Competitiveness. Procedia Social and Behavioral Sciences vol.124, pp. 405-411 (2014).

19. Söylemezoglu E., Doruk O. T.: Are Clusters Efficiente for the Relation Betweem Milk Production and Value Added per Capita in Regional Level? An Empirical Assessment. Proc. Social Behav. Sciences 150, 1277-1286 (2014).

20. Tsai-Ju, L. Local clusters of SOEs, POEs, and FIEs, internacional experience, and the performece of foreign firms operating in the emerging economies. International Business Review 24 (2015).

21. Bohlander, G. W.; Snell, S. A. Administracao de recursos humanos. Cengage, Sao Paulo (2015).

22. Hahn, M. H., Lee C., Lee D. S.: Network Structure, Organizational Learning Culture, and Employee Creativity in System Integration Companies: The Mediating Effects of Exploitation and Exploration. Contents in Human Behavior. 42, pp.167-175 (2015).

23. Vieira, S. Como Elaborar Questionários, volume 1. Atlas, São Paulo (2009).

24. Pereira, J. C. R. Análise de dados qualitativos: estrategias metodológicas para as ciências da saúde, humanas e sociais. 2 ed. São Paulo: Edusp, pp 65-66 (1999).

25. IPARDES. Caderno estatístico município de Umuarama, http://www.ipardes.gov.br, last acessed 2017/03/01. 